STRATEGIC ANALYSIS 


\title{
THE VISEGRAD GROUP IN THE WESTERN SECURITY SYSTEM
}

\author{
Marcin URBAŃSKI \\ National Defence University, Warsaw, Poland \\ Karol DOŁĘGA \\ Siedlce University of Natural Sciences and Humanities
}

\begin{abstract}
The catalyst for the initiation of regional integration processes in Central and Eastern Europe was the erosion of the system of real socialism. The security vacuum created after the collapse of the Soviet Union allowed the countries of the region to establish low institutionalised cooperation towards integration with NATO and the European Union - the two basic pillars of the Western security system. Apart from presenting the process of the quadrilateral cooperation of Poland, the Czech Republic, Slovakia and Hungary for independence from the Soviet Union and then the Russian Federation, and integration with NATO and the EU, the authors also focus on the joint actions of the Visegrad Group after joining Western structures. A particularly important area of analysis is military cooperation and its tangible consequences - closer cooperation between the Central European region and, consequently, increasing the level of security.
\end{abstract}

Key words: The Visegrad Group, North Atlantic Treaty Organisation (NATO), European Union (UE), Central Europe in 1945-1989, Central Europe in 1991-2004, foreign policy, integrated security

\section{Introduction}

Visegrad - a village rising on the hill, on the banks of the Danube in Hungary. The rich history of this place, especially the kings of Hungary - Charles Robert, Poland - Casimir III the Great, Czech - John the Blind and the rulers of Bavaria, Saxony 
and Moravia meeting there in 1335 and 1338 created the foundations for the Prime Minister of Hungary - Jozsef Antall and the presidents of Czechoslovakia - Vaclaw Havel and the Republic of Poland - Lech Walesa also meeting there. As a result of the agreement in 1991, the Visegrad Triangle was created.

The main theme of the article is to examine the origins, creation and functioning of the so-called Visegrad Group. The authors try to draw attention to the aspects relating to events that had a particular impact in history on the emergence, establishment and interaction of these three and then four states in Central Europe.

The need to write this article stems from the fact that the events of recent years, primarily the geopolitical changes in Eastern Europe, Russia's war with Georgia in 2008, the still unresolved conflict with Ukraine, the issue of terrorism, refugees and organised crime, threaten the security of the Central European region. Poland, Hungary, the Czech Republic and Slovakia, jointly working together as part of the Visegrad Group, can strengthen the guarantees of their own security in the European Union and NATO. But this is not an easy process. Taking into account the difficult history and divisions that accompanied the signing of the Declaration in Visegrad, it required a lot of negotiations, disputes and, consequently, concessions to develop consensus among the V4 countries.

The issues that the authors raise in this article deal with:

- Yalta order and coexistence in the Soviet sphere of influence;

- The fall of the Iron Curtain - the joint efforts of the Visegrad Group countries for integration with NATO and the EU;

- The Visegrad Group's operations in the Western security system - selected projects of V4 within NATO and the European Union.

Taking all the above into consideration, the publication probably does not present a comprehensive picture of the new international situation in this part of Europe, but indicates a variety of problems that the Visegrad Group encounters in its work. What's more, the Western security system, in which the group operates, requires the commitment and adjustment of their decisions that would comply with generally accepted principles and values prevailing in the European Union and NATO. As a consequence, the analysis of the events that take place in the Western security system and cover the Visegrad Group, demands reliable and accurate observation from the authors. 
Owing to this, the publication puts forward complex factors connected with the activity of the Visegrad Group in the European arena in the face of constantly changing international reality.

\section{Yalta order - co-existence in the Soviet sphere of influence}

The Yalta Conference in the Crimea in February 1945 launched the establishment of a new international order. Post-Yalta order was established by three leaders of the victorious powers in World War II: Joseph Stalin, Winston Churchill and Franklin Delano Roosevelt. The Crimean peninsula became the place where a crucial decision for the future of Central and Eastern Europe was taken. Later, it turned out, it became fundamental for relations between the military and political forces in Europe. The Soviet yoke covered the countries east of the Elbe, and the phenomenon was most accurately described by Winston Churchill, who used the term "iron curtain" (Map 1).

Accordingly, the states which the following article deals with, i.e. Poland, Hungary and Czechoslovakia were, in the period of post-Yalta order, under the jurisdiction of the Soviet Union and its communist government. In the next part of the publication, the authors make an attempt to present the consistency or inconsistency of the interests of these countries in the postwar period until the Autumn of Nations, the fall of the Berlin Wall in 1990 - a symbol of the end of communism and two-bloc system in Europe. The characteristics of the foreign policy of these countries, which in the early nineties set up the Visegrad Triangle and later the Visegrad Group, will also allow the premises and the objectives which they adopted when they created the initiative of the alliance to be perceived.

1 The definition of "iron curtain” Winston Churchill usedon March 5, 1946 in a speech in Fulton (Missouri), he said the following words: From Stettin in the Baltic to Trieste in the Adriatic, an iron curtain has descended across the Continent. Behind that line lie all the capitals of the ancient states of central and eastern Europe. Warsaw, Berlin, Prague, Vienna, Budapest, Belgrade, Bucharest and Sofia, all these famous cities and the populations around them lie in the Soviet sphere and all are subject in one form or another, not only to Soviet influence but to a very high and increasing measure of control from Moscow. 


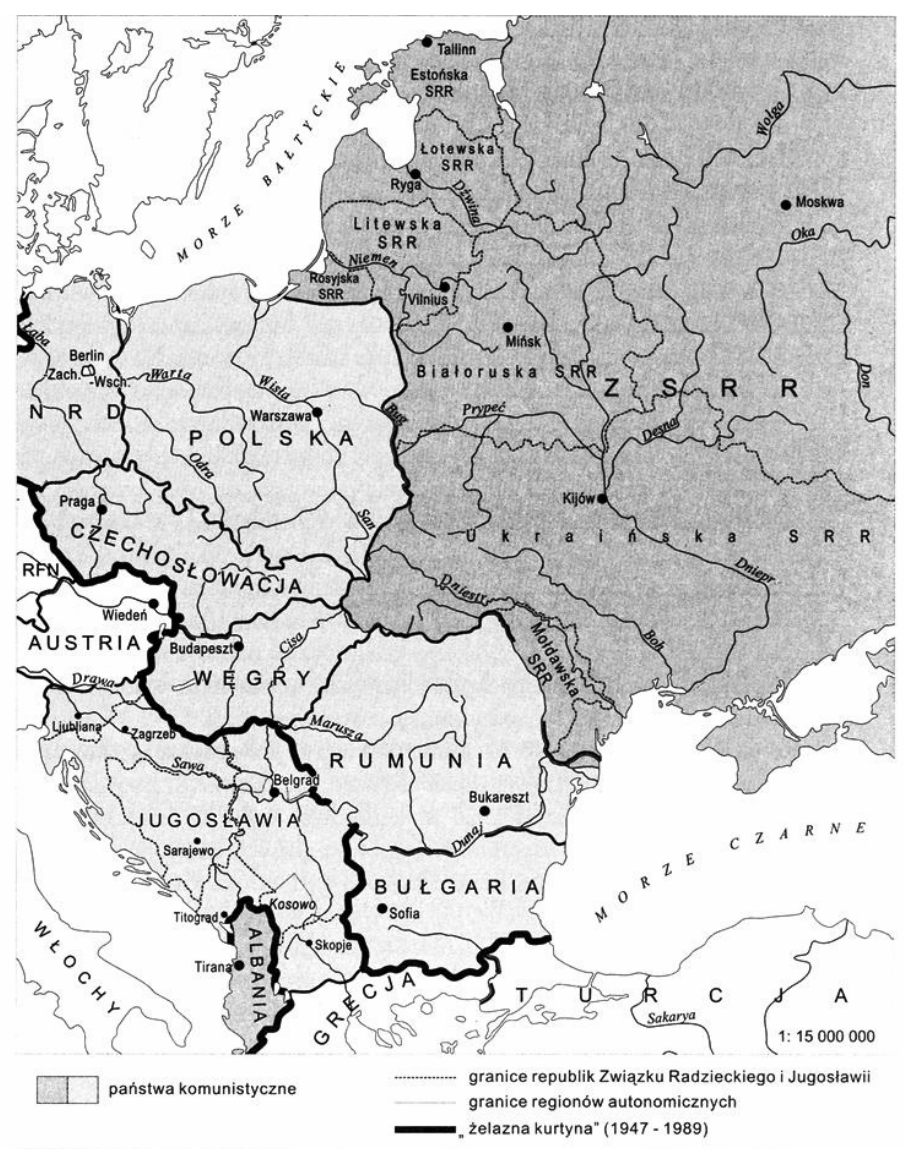

Source: P. Wandycz, Wiek XX, [w:] „Historia Europy Środkowo-Wschodniej, t. 1, J. Kłoczkowski (red.), Instytut Europy Środkowo-Wschodniej, Lublin 2000, s. 504.

\section{Map 1. The political situation in 1955-1989}

After the end of World War II, until March 1953, the jurisdiction over the states of the Soviet bloc was held by Generalissimo Joseph Stalin. His death shocked the entire community of the communist world, which also weakened relations between the USSR and the countries which were ruled by the political parties subordinate to Moscow. The year 1956 brought a political breakthrough in Poland. The public expressed opposition to Stalinism by their protests, which was met with Nikita Khrushchev's discontent, who was in Warsaw at that time. "The Polish October" could have led to the intervention of Soviet troops on the territory of the Republic of Poland, which, in the end, did not occur. The revisionism of communism in Poland got a lot of publicity abroad, the Hungarians proved to 
be particularly loyal to the Poles. The USSR was not as lenient towards Hungary as it was towards Poland. The demonstrations in Budapest in solidarity with the changes in Poland led to the outbreak of fighting on a large scale and, thus, to the military intervention of the Soviet Union troops ${ }^{2}$. Taking into consideration the events which occurred in Hungary, apart from the internal reasons that largely determined the incidents on the Danube ${ }^{3}$, the authors focus on external conditions. The "October detonator" in Poland is one of the most important ones. The aim, however, is not to present the course of the events of the military intervention in Hungary but to articulate the most important determinants of the bilateral relations that united the neighboring countries. The most important primarily include the anti-Soviet and anti-communist basis of the disturbances in the two countries. In the view of the Kremlin, Poland, together with Hungary undermined the hegemonic order in the region of Eastern Europe and, what is more, they dared to challenge the rules imposed by the Soviet Union ${ }^{4}$. Although there was no fighting with the Red Army in Poland, the events of that period showed that, in the societies of Central and Eastern Europe, there was a growing awareness of regaining independence and self-reliance. Despite the fact that these countries had to wait nearly three decades to escape Soviet oppression, it made the authorities in Moscow realise that it would bring about the slow stagnation of the communist system. Therefore, since the 1960s, the USSR Soviet began to lead in its spheres of influence with greater caution. The example of Hungary made the authorities in the Kremlin realise that they could not approve of more of these types of incidents in the block. This would more likely cause "a domino effect" in other countries. Therefore, the intervention of the Soviet Union had a preventive and not only a reactionary character and its function was to inform the other members of the soviet zone, that all manifestations of revolt would be suppressed by force ${ }^{5}$.

The third country in the region is Czechoslovakia, which, after World War II, was entirely subordinated to the USSR. This fact is not revealing considering the

2 P. Wandycz, Wiek XX [w:] „Historia Europy Środkowo-Wschodniej”, J. Kłoczowski (red.), Instytut Europy Środkowo-Wschodniej, Lublin 2000, s. 503.

3 Zob.: E. Czarkowska, Interwencja Zwiazku Radzieckiego na Wegrzech w 1956 r., Wydawnictwo Adam Marszałek, Toruń 2007

4 Ibidem, s. 115.

5 Ibidem. 
post-war situation in the region. The authors, however, point to the completely different circumstances from those of the above-mentioned countries. This is so because, since the end of the war, the communists had gained full power in Czechoslovakia. This meant that its economic and cultural policy, as well as its suppression system, did not practically differ from that of the Soviet Union. However, the system of implementing communism was different. The Soviet Union treated Czechoslovakia in a more "friendly" way. They withdrew troops from the area as early as 1948 and, in the case of Poland, this only took place in $1992^{6}$. Furthermore, it has to be remembered that the Polish and Hungarian societies were anti-Russian and anti-communist, as opposed to the Czechs and Slovaks?

As a result, all the countries mentioned above were under the influence of the soviet protectorate until the fall of the Berlin Wall. Foreign policy and security policy in Poland, Hungary and Czechoslovakia was fully dependent on the decisions of the communist superpower. The events of the 1950s showed that the USSR began to move away from the rigid and adventurous course which had been outlined by Joseph Stalin ${ }^{8}$. The methods of repression were tempered, however, and they did not abandon the tough policy, which was confirmed by the "Prague Spring" and the intervention in 1968 by Warsaw Pact troops in Czechoslovakia.

Taking into consideration the political reality in the times of "the cold war", the countries of Central and Eastern Europe believed that the most reasonable solution to the situation of being subordinate to the Soviet Union was to integrate. Joining forces and resources, developing a common foreign policy would enable to them become independent from the power in the Kremlin.

The strongest argument for the foundations of the emergence of the Visegrad Triangle in 1991 was the geographical location of these countries in the middle of the European continent. The possibility of dividing this part of Europe by the aforementioned "iron curtain" also had an influence on the creation of the Visegrad Triangle. Once more, in such a short time, Central Europe became a buffer zone

6 Z. Jirasek, A. Małkiewicz, Polska i Czechostowacja w dobie stalinizmu (1948-1956). Studium porównawcze, Instytut Studiów Politycznych PAN, Warszawa 2005, s. 384-385.

7 Ibidem, s. 386.

8 A. Czubiński, Europa XX weku, Wydawnictwo Poznańskie, Poznań 2008, s. 314. 
between the West and the East, between the North Atlantic Treaty Organisation and the Warsaw Pact. Such a position could have potentially become a source of tension and the area of possible armed conflict between opposing military alliances ${ }^{9}$.

Despite several attempts to subordinate Central and Eastern Europe entirely, the Soviet Union managed maintain its influence temporarily and merely superficially. With the end of a two-bloc division of the world, an economically declining Soviet Union began to walk away from Central Europe. The events in the late 1970s in Poland initiated the progress in the move to return "to Europe" under the slogan of "transformation". In addition, it was also the result of other circumstances, such as the events in June 1976, Karol Wojtyła's election as Pope and the establishment of "Solidarity" in 1980. In Hungary, the most stable country of the communist bloc, "goulash communism" ${ }^{10}$ resulted in a change in the mood of society and, as in other countries of the "Autumn of Nations", the Hungarians began to introduce reforms which were leading towards the capitalist economy. After the "Prague Spring", with the purges and repressions against society, Czechoslovakia began to move back from the criticism of the authorities in Moscow. The circumstances of perestroika changed this approach. In addition, the events in Poland and Hungary led to the "velvet revolution", which, in consequence, made the communists give up power.

In an attempt to show the relations and connections between the states that formed the Visegrad Triangle in the early 1990s, it should be remembered that the idea of integration had its basis in bilateral agreements. Such a situation primarily originated in the cooperation within the Council for Mutual Economic Assistance ${ }^{11}$. This mainly concerned the development of foreign policy and strengthening mutual relations. The bilateral agreements between the countries fulfilled the

9 J. Panek, Czechy a Polska na progu czasów nowożytnych, Wydawnictwo Adam Marszałek, Toruń 2014, s. 71.

10 Goulash communism (Hung. Gulyáskommunizmus) or kadarism (from János Kádár) - variety of real socialism, the informal name of the Hungarian People's Republic regime from the 60s. until the restoration of capitalism in Hungary in 1989. Goulash communism broke with the principles of early Stalinism, following more closely the human rights and introducing elements of the free market.

11 Zob. L. Ciamaga, Od wspótpracy do integracji : zarys organizacji i działalności w latach 1949-1964, „Książka i Wiedza”, Warszawa 1965. 
role of consolidation in ensuring their own security and their relationship with European security as such. Their aim was to be guided by equality, respect for sovereignty and non-interference in internal affairs. From the point of view of the whole soviet bloc, the necessity for consultation was significant, which enabled overcoming problems, working out solutions, as well as a common stand. Additionally, the states committed themselves to the principles of the UN Charter. The agreements also included regulations concerning the following fields: science and technology, the economy, culture, health, education, literature, art, radio, television, and many others.

Another argument for searching for the method of integration was the lack of a discussion forum within the framework of the Warsaw Pact. The hegemony of the Soviet Union did not allow the structure of the alliance to be escaped from, much less to follow the example of NATO and the EEC, which were functioning efficiently. The repressions in Poland, Hungary and Czechoslovakia resulted in the erosion of the current communist political system. It was also caused by the decomposition of state structures, as well as breaking off ideological, political, military and economic ties between the countries ${ }^{12}$. Despite signing bilateral agreements, they could not always be used to implement new projects. The concepts of symmetric subregional solutions, described colloquially as regionalism, constituted a method of dealing with the situation. Owing to regionalism, Central and Eastern Europe became a region which was strategically important in politics, both in the communist and in the capitalist bloc. People finally starting appreciating the distinctiveness of the region, which was similar with regard to the socio-economic structure, cultural identity with its common past, the perception of the same ideas and cultural trends ${ }^{13}$. The authors of this publication believe that, apart from the abovementioned arguments, there are other justified arguments made by Remigiusz Bierzanek, who underlined "natural closeness" and "political necessity" as well ${ }^{14}$. According to Andrzej Czarnocki, all

12 J. Kukułka, Historia wspótczesna stosunków międzynarodowych 1945-1994, Wydawnictwo Naukowe „Scholar”, Warszawa 1994, s. 441.

13 B. Osadnik, Nowy regionalizm w Europie Środkowo-Wschodniej. Grupa Wyszehradzka [w:] „Bezpieczeństwo państw Grupy Wyszehradzkiej. Nadzieje i realia”, J. Przewłocki, B. Osadnik (red.), Wydawnictwo Uniwersytetu Śląskiego, Katowice 1995 r., 19.

14 R. Bierzanek, Wspótczesne stosunki międzynarodowe, Państwowy Instytut Wydawniczy, Warszawa 1980, s. 280. 
the components of the concept of regionalism are part of a dynamic process of the rapprochement of the participants in the international environment which was constituted by the quantitative and qualitative growth of the interaction and forming norms and international institutions" ${ }^{15}$. Taking into account all the above characteristic features of the East and Central European region, one may conclude that they indicated an inevitable integration.

The first clear symbol of institutionalisation of the cooperation between Poland, Czechoslovakia and Hungary was the Central European Initiative. Although, at the beginning, it was formed by Austria, Yugoslavia, Hungary and Italy, soon it accepted Czechoslovakia, creating the so-called "Pentagonale". The group's objective was mainly to stabilise the relations in Central Europe, develop the Danube, transport connections modernisation, nuclear safety and formworking groups which would deal with other problems ${ }^{16}$. At the end of the 1980s, Zbigniew Brzeziński, referring to the initiatives put forward by Wladysław Sikorski and Edward Benes during World War II, advocated the initiative of reactivating the idea of creating a Polish and Czech federation ${ }^{17}$. Poland, at the beginning of the group's activity, was not welcome in its ranks, mainly because of its attitude towards Czechoslovakia. Vaclaw Havel, during a meeting in Bratislava in April 1990, stated that Poland can at best be a link between the South and the Nordic countries, because to all intents and purposes it fitted neither group ${ }^{18}$. In addition, the president of Czechoslovakia paid his first visit to the GDR and FRN, which disappointed public opinion in Poland and was a sign that an agreement between the two countries would not be easy to reach. Later, however, under the influence of the support given to Poland by Hungary and Italy, and especially the Italian foreign minister Gianni de Mechelisa, who, in 1991 in Parma, stated that "We must not leave Poland between the two powers in a situation when the creation of a pan-European security system is still quite distant ${ }^{19}$, he changed his mind, which resulted in Polish accession to the initiative, which was called

15 A. Czarnocki, Europa jako region wspótistnienia Wschód - Zachód w latach 1972-1989, Wydawnictwo Uniwersytet Marii Curie-Skłodowskiej, Lublin 1991, s. 16.

16 J. Kukułka, op. cit., s. 443.

17 R. Zięba, „Nowy regionalizm” w Europie a Polska, „Sprawy Międzynarodowe”, Zeszyt 1-2/455/1992, PISM Warszawa, s. 27.

18 W. Pawłowski, Trójkąt, sześciokat i reszta Europy, „Polityka”, 23.02.1991 r., s. 9.

19 Cyt. za J. Wiejacz, Grupa Pentagonale i miejsce Polski, „Polska w Europie”, czerwiec 1991 r., s. 87. 
"Hexagonale" at that time. Thanks to the Central European Initiative, a "Central European triangle" emerged. Despite the exchange of views on cooperation between the three countries, an attempt at institutionalization was still not made. Additionally, President Havel, when asked about the common future, stated that he was only interested in NATO, which was the only democratic and tested at the time institution that was able to guarantee security ${ }^{20}$. Over the course of time, the authorities in Czechoslovakia changed their attitude. The three of them initiated economic and military consultations. They were the beginning of a sub-regional cooperation mechanism, which, in the future, was to be independent of Comecon and the EEC. In reality, however, the countries tried by all possible means to "return to Europe" and avoid rivalry between each other to be first to join NATO structures and European Communities ${ }^{21}$.

Polish, Hungarian and Czech efforts to reach a common stance in Central Europe did not remain unnoticed by the North Atlantic Treaty Organization. NATO member countries have openly began to take the initiative to strengthen cooperation. However, this was not the main reason for NATO's interest. In view of the forthcoming collapse of the Warsaw Pact, NATO sought to fill the gap created by the presence of the Warsaw Pact in Central Europe. The countries of the "Visegrad Triangle", thanks to the strongest economy in the region, the advancement of economic and social reforms, geographic proximity and the universality of the democratic processes, were able to fill this space ${ }^{22}$. Moreover, the idea of the creation of the Visegrad Triangle formed part of a new form of cooperation adequate to the situation after the collapse of the communist system. It should also be recognised that the process of trilateral integration, despite clear common characteristics which united these states, was not as simple as it might have seemed. The events in the past which occurred between particular countries, including territorial and ethnic problems and different political perception, are particularly conspicuous ${ }^{23}$. It is also important to remember the conflicts on the

20 W. Pawłowski, Trójkąt, sześciokąt i reszta Europy, „Polityka”, 23.02 .1991 r., s. 9.

21 J. Kukułka, op. cit., s. 443.

22 F. Gołembski, Grupa Wyszehradzka - próba realizacji koncepcji wielostronnej wspótpracy w Europie Srodkowej, „Sprawy międzynarodowe”, Zeszyt 3 (XLVII) 1994, PISM Warszawa, s. 62.

23 Ibidem, s. 62. 
border of Hungary and Slovakia, the Sudeten question and the Polish-Czech issue $^{24}$.

In conclusion, the second half of the twentieth century and, most of all, the events in the late e1980s, whwhose culmination was "the Autumn of Nations" with the ultimate collapse of the socialist system in Europe, showed how determined the countries were to abandon the jurisdiction of the Union of Soviet Socialist Republics. Of the many attempts to integrate Poland, Hungary and Czechoslovakia, only the Visegrad Triangle identified common interests, goals and directions of foreign and security policy. Disagreement and, especially, Soviet repression towards Central and Eastern European countries had a negative influence on working out a common stance.

Due to state repression, jointly opposed by Moscow, which negatively affected the development of a unified position, the period of "post-Yalta order" in Central and Eastern Europe, at the beginning of the 1990s, has exposed the weakness of the communist system to integrate, manifested first in the Visegrad Triangle uprising and later in their accession to NATO and the EU.

\section{The fall of the Iron Curtain - the joint efforts of the Visegrad Group countries for integration with NATO and the EU}

The collapse of the real socialism system in the area of Central and Eastern European countries enabled this part of the continent to redefine its foreign policy towards the West. The platform to implement t pro-Western orientation was, firstly, the desire to eliminate economic and military structures, bringing together countries which were under the umbrella of the Soviet Union - the Council for Mutual Economic Assistance and the Warsaw Pact and, secondly, accession, and in the

24 Zob. szerzej: Grupa Wyszehradzka - 20 lat wspótpracy, A. Czyż, „Atheneum” Polskie Studia Polityczne, 42/2014, Wydawnictwo Adam Marszałek, s. 12-14 i dalsze; Czechy a Polska na progu czasów nowożytnych, J. Panek, Wydawnictwo Adam Marszałek, Toruń 2014, s. 33-34. 
long term, full integration with the European Union and $\mathrm{NATO}^{25}$. The purpose of this part of the article is to present the joint effort of the Visegrad Group to join the Western security system.

Proclamation of the Visegrad format was preceded by a phenomenon known as "new regionalism” which strengthened international cooperation in a specific geographic region in order to overcome divisions existing in Europe. Establishing regional cooperation by individual countries also resulted, and perhaps above all, in the multiplication of mutual benefits in the process of integration with Western Europe. In other words, countries with similar historical, cultural, social, economic and political identity, which were to adopt an identical platform of negotiations, in many respects, would become more visible in the international arena, and the consequence of their joint efforts would be the effect of synergy in striving for full integration with Western economic and security structures.

The practical implementation of the idea of a new regionalism was initiated by the cooperation between Adriatic-Danubian countries (Hungary, Yugoslavia, Austria and Italy) in November 1989. In 1990, Czechoslovakia joined the aforementioned group, followed by Poland in 1991. In the following year, as a result of the division of Yugoslavia - Bosnia and Herzegovina, Slovenia and Croatia joined the initiative. Another form of regional cooperation in the early 1990s was the cooperation of the Baltic countries, on the basis of which the Council of Baltic Sea States was established. The authors of this article are interested in the third dimension of international cooperation which developed in Central Europe, namely the Visegrad Triangle established in 1991,bringing together Poland, Czechoslovakia and Hungary ${ }^{26}$.

Declaration on cooperation between the Czech and Slovak Federal Republic, the Republic of Poland and the Republic of Hungary in striving for European integration signed on 15 February 1991, set five basic goals for the signatories to the document:

- full restoration of state independence, democracy and freedom,

- elimination of all existing social and spiritual symptoms of the totalitarian system,

25 P. Deszczyński, M. Szczepaniak, Grupa Wyszehradzka. Wspótpraca polityczna i gospodarcza, Wyd. Adam Marszałek, Toruń 1995, s. 5.

26 Ibidem, s. 5- 6. 
- construction of a parliamentary democracy, a modern state of law, respect for human rights and fundamental freedoms,

- the creation of a modern market economy,

- inclusion in the full range of the European political and economic system, and systems of security and legislation ${ }^{27}$.

The most important goal of the member countries constituting the Visegrad Triangle was undoubtedly integration with Euro-Atlantic structures, which was confirmed by the title of the declaration itself. Analysing the goals contained in the above declaration, it can be considered that the implementation of the first four is a sine qua non for the full realisation of the latter.

In structural terms, the Visegrad Three had no institutional base. Cooperation is based on a rotating chairmanship and meetings of the representatives of the member states ${ }^{28}$. The only institutionalised form of cooperation is the International Visegrad Fund with the Secretariat located in Bratislava ${ }^{29}$.

A consequence of the low level of institutionalisation was the high susceptibility of the Triangle to the political situation in the member states ${ }^{30}$. In practice, the intensity and effectiveness of the community depended on the attitude of particular political forces of a given country to the Visegrad idea. For example, the "Velvet Divorce" between Czechoslovakia and Slovakia on 1 January 1993 and Václav Klaus taking control in the Czech Republic, caused a slowdown in cooperation within the Visegrad Group ${ }^{31}$. V. Klaus believed that the Czech Republic, as the most developed former communist country, would be integrated much more quickly with the European Economic Community than if it sought to integrate

27 Deklaracja Wyszehradzka 1991, http://www.visegradgroup.eu/documents/visegraddeclarations/visegrad-declaration-110412-2, (dostęp: 14.12.2015).

28 P. Bukalska, Punkt widzenia. Nowa Grupa Wyszehradzka w nowej Unii Europejskiej - szanse i możliwości rozwoju, Wyd. Ośrodek Studiów Wschodnich, Warszawa 2003, s. 15.

29 Międzynarodowy Fundusz Wyszehradzki, http://visegradfund.org/about/ (dostęp: 14.12.2015 r.).

30 P. Bukalska, op. cit., s. 14.

31 In connection with the division of Czechoslovakia into two countries: the Czech Republic and Slovakia Triangle changed its name to the Visegrad Group. 
together with its neighbours from the region. In addition, Klaus was reluctant to accept Polish ambitions to speak with one voice on behalf of the entire Group ${ }^{32}$.

However, before the limitations of cooperation within the Group, it is necessary to pay attention to the actions taken up to this point by the member states and to indicate the results of this cooperation in the context of integration with NATO and the European Union.

One of the most striking successes of the Group was helping to dissolve the structures which made Visegrad states dependent on the Soviet Union, namely the Council for Mutual Economic Assistance and the Warsaw Pact. The talks at the level of the Political Consultative Committee - the highest political body of the Pact, held from June to November 1990, were really important from the perspective of the dissolution of the Warsaw Pact. The common stance of Poland, Czechoslovakia and Hungary enabled these countries to explain and agree on their needs in terms of security, and then spell it out to the policy-makers in the Soviet Union. Despite their relatively weak position at the beginning of the negotiations, the united front of the Central European countries caused them to become independent of Moscow and brought about the dismantling of the whole structure of the Warsaw Pact, and not just its restructuring ${ }^{33}$.

The dismantling of this structure led to the withdrawal of the Red Army units in the territories of Hungary and Czechoslovakia in1991 and Poland in 1993.

Coordination of the security policy of the Visegrad countries also contributed to the effective resistance to Moscow's pressure to include, in already signed bilateral agreements on friendship and cooperation between the member countries of Triangle and the Soviet Union, clauses prohibiting them from joining the structure of the "hostile" alliances. If these clauses had been signed, it would have complicate the process of the integration of the Visegrad Group with The North Atlantic Alliance and would have left them under the influence of the Soviet Union ${ }^{34}$.

32 K. Gawron - Tabor, Wspótpraca państw Grupy Wyszehradzkiej w procesie integracji europejskiej w latach 1989 - 2009, Dom Wydawniczy DUET, Toruń 2013, s. 115-116.

33 Ibidem, s. 104.

34 Ibidem, s. 105. 
Due to the fact that, in 1991, many goals were achieved through mutual cooperation, the Visegrad countries were faced with a difficult challenge of filling the so-called security vacuum created in Central Europe after the dismantling of the Warsaw Pact. As a result, the next meetings mainly concerned security issues.

Security issues were discussed at the summit organised between $5^{\text {th }}$ and $6^{\text {th }}$ October 1991 in Krakow, which was attended by foreign ministers of the Triangle: Jiri Dienstbier, Géza Jeszenszky and Krzysztof Skubiszewski. During the meeting, the Czech draft of a message to NATO was analysed, which then underwent some minor amendments and was accepted as a statement of the three foreign ministers concerning cooperation with NATO. An important part of the statement in the context of a verbalisation of the Polish, Czech and Hungarian efforts to join the Alliance was a statement that in Europe there is no place for different types and different levels of security. Security should be the same for everybody. The foreign ministers are of the opinion that the existing formula of diplomatic relations [...] needs to be significantly expanded in order to create conditions for the direct involvement of the Republic of Poland, Czechoslovakia and Hungary in the activities of the Alliance ${ }^{35}$.

The Declaration was accepted on 6 October 1991 in Krakow and it was stated that the existing cooperation in the Triangle makes an important contribution to shaping a new democratic international order in the region of Central Europe. The main aim of including Poland, Czechoslovakia and Hungary in the European political, legal, economic and security systems was also emphasised. The attempts to associate with the European Economic Community and to enhance the cooperation with NATO and the Western European Union, which is a pillar of the Atlantic Alliance, were a means of achieving this goal ${ }^{36}$.

At the next summit, which took place in Prague on 6 May 1992, a commitment to the further preparations for accession to the European Union was taken and further development of relations with NATO, leading to full membership, was announced $^{37}$.

35 M. Herman, Grupa Wyszehradzka. Narodziny, rozwój, perspektywy, Polski Przegląd Dyplomatyczny, Nr 2/2001, s. 172-173.

36 P. Deszczyński, M. Szczepaniak, op. cit., s. 13.

37 M. Herman, op. cit. s. 174. 
In the coming months, Visegrad cooperation waslimited, due to the aforementioned disintegration of Czechoslovakia and retreat from the idea of Visegrad which had been advocated by Klaus's government. Selfish Czech policy in the pursuit of integration with Western security structures, often faced criticism from Western politicians. Niels H. Petersen - Minister of Foreign Affairs of Denmark - stated that the West supported the cooperation of the Visegrad Group not tolerating the individualism of any of these states. He added that only games in the "quartet" can bring tangible results, and the „soloists" must leave the scene ${ }^{38}$.

Although, since 1993, the Visegrad Group has entered a phase of limited cooperation, it was still the overriding objective of each of the members to integrate with NATO and the European Union ${ }^{39}$. Taking into account NATO's aim to integrate the Visegrad countries with the Alliance, it is necessary to highlight some fundamental limitations of the Alliance resulting from the specificity of the contemporary international security environment, which included:

- fear of antagonising Russia,

- fear of involving NATO in the ethnic conflicts in the region of Central Europe,

- fear of a situation in which an invitation to join the Alliance for one country would cause a rapid influx of requests from other states and, for political reasons, it would be difficult to reject them ${ }^{40}$.

The issue of potential Russian opposition in the context of the integration of Poland and other countries of the Visegrad Group with NATO was solved relatively easily. During the visit of the Russian President Boris Yeltsin to Warsaw on 25 August 1993, the "Joint Polish - Russian Declaration” was signed and it stated that the decision of Poland to join NATO is not contrary to the interests of other countries, including Russia ${ }^{41}$. In a similar vein, Boris Yeltsin also spoke the next day in Prague and Bratislava in relation to the issue of NATO membership of the

38 Ibidem, s. 179.

39 The least distinctive policy in this area led Slovakia. Because of the difficulty after the division of Czechoslovakia Slovak authorities pursued a policy of multidirectional, also including Russia, Ukraine and Romania in their visions of safety.

40 P. Deszczyński, M. Szczepaniak, op. cit., s. 31.

41 K. Pełczyńska - Nałęcz, Stosunki polityczne między Polską a Rosja po 1990 r. [w:] A.D. Rotfeld, A. W. Torkunow (red.), Biate plamy - Czarne plamy. Sprawy trudne w polsko-rosyjskich stosunkach 1918-2008, Polski Instytut Spraw Międzynarodowych, Warszawa 2010, s. 892. 
Czech Republic and Slovakia. Although the above statements did not solve the problem of Russian objections to the transition to the Western security system of Central European countries clearly, they undoubtedly equipped the Central and Western policy makers with strong arguments which were in favour of including these countries into NATO structures.

One of the results of the August declarations was the adoption by NATO member states of a formula called the „Partnership for Peace” during a meeting that took place in Travemünde between $20^{\text {th }}$ and $21^{\text {st }}$ October 1993. The purpose of this undertaking was to enable all the former Soviet Union satellite states to cooperate with NATO and for some of them to join the Alliance. The final shape of the new NATO programme was approved on $11^{\text {th }}$ January 1994, during the NATO summit in Brussels. Although the adoption of the "Partnership for Peace” programme was an important event in Europe, the Visegrad countries were not particularly distinguished as compared to some other former Warsaw Pact countries ${ }^{42}$.

Despite the suspension of political cooperation within the Group, the annual tripartite meetings at the level of Defence Ministers were not abandoned (without the participation of the Czech Minister). The agenda of the meetings focused mainly on issues related to the Polish, Hungarian and Slovak road to membership in NATO and, consequently, the objections of the Russian Federation. Military cooperation also enabled the effective transformation of the armed forces to meet NATO standards ${ }^{43}$.

The intensification of the military cooperation came after the Madrid NATO summit on 8 June 1997 where it was decided that Poland, the Czech Republic and Hungary were invited to join the Alliance. As a result, as early as in July 1997, at a meeting of the Group's defence ministers in Budapest, it was decided that regular, quarterly meetings at ministerial level were going to be held. In addition, deputy ministers and chiefs of staff were going to consult each other as well ${ }^{44}$.

The cooperation of the Visegrad countries in the context of NATO membership also included foreign ministers, who through regular consultations regarding

42 P. Deszczyński, M. Szczepaniak, op. cit., s. 31-32.

43 K. Gawron-abor, op. cit., s. 162-163.

44 Ibidem, s. 164. 
issues related to NATO accession, agreed on a common stance. As a result of joint ventures involving, inter alia coordination of national ratification procedures and joint lobbying in parliaments of the NATO member states, Poland, the Czech Republic and Hungary, officially joined in the structure of the largest military alliance in the world - NATO, in March 199945.

Slovakia was the only Visegrad country which was outside the North Atlantic Alliance in 1999. The difficult economic situation in the country right after the "Velvet Divorce” prevented rapid integration with the European Union and consequently blocked the prospect of the inclusion of Slovakia in Western economic and security structures. Therefore, there were frequent opinions which suggested the neutral or eastern, pan-slavic orientation of this country. Such opinions were confirmed by Slovak representatives' visits to Russia, Romania and Ukraine. From the NATO perspective, Slovak relations with the Russian Federation were particularly important, as they often resulted in signing intergovernmental and interdepartmental agreements. Another element that separated Poland's southern neighbour from NATO was a referendum held from 23 to 24 May, 1997. The subject of the referendum was Slovak membership of the Alliance. Due to the low turnout, which reached only $9.5 \%$, the referendum was invalidated ${ }^{46}$.

Rudolf Schuster's victory in the second round of presidential elections in Slovakia, conducted on 29 May 1999 enabled the country to return to cyclical meetings within the Visegrad Group and to the idea of pro-Western integration. The new president, in the first speech during his swearing-in ceremony on 15 June 1999, pointed out that it would be extremely beneficial if Slovakia fulfilled the conditions of admission to the European Union and should become part of the collective security system within NATO as soon as possible. Slovakia does not want to lag behind its closest neighbors: Poland, the Czech Republic and Hungary ${ }^{47}$.

With the reintegration with the Visegrad Group, whose members joined NATO in 1999, Slovakia received the firm and strong support of the region in its efforts to join the Alliance. It was confirmed by the statement given to journalists by the

45 Ibidem, s. 165.

46 M. Herman, op. cit. s. 178-183.

47 Participation in the ceremony of swearing in of President of Slovakia, https://www. bbn.gov.pl/pl/wydarzenia/267,Udzial-w-uroczystosci-zaprzysiezenia-prezydenta-Slowacji. html (dostęp 1.01.2016 r.). 
then Polish President, Aleksander Kwasniewski: Poland wants to be a lawyer, both in terms of joining NATO and the European Union. Slovakia is treated not only as a good neighbour, but as a very important partner ${ }^{48}$.

The consistent actions of the government and the President and the support from the partners of the Visegrad Group resulted in the invitation for Slovakia, the Baltic States, Romania, Bulgaria and Slovenia to join NATO, which was issued at the Prague Summit on $21^{\text {st }}$ and $22^{\text {nd }}$ November. Slovakia officially became a member of NATO on 29 March 2004, making its membership a fundamental element of its security and defence polic ${ }^{49}$.

The accession of the Visegrad countries to NATO fulfilled a security grey area created in Central Europe after the dissolution of the Warsaw Pact. Parallel to accession efforts with NATO, the Visegrad countries tried to join the European Union as soon as possible to engage fully in the European political, economic and legal systems. Polish, Czech and Hungarian procedure for admission to the European Union was launched on 31 March 1998 and on 15 February 2000 in Slovakia's case.

Considering the issue of the joint efforts of the Visegrad Group countries for integration with the European Union, it should be noted that, despite the official name of the document establishing the Visegrad format: Declaration on cooperation between the Czech and Slovak Federal Republic, the Republic of Poland and the Republic of Hungary in striving for European integration, the real cooperation in the phase of accession negotiations was little, and the meetings held among the Visegrad countries during negotiations with the Union were merely informative and consultative.

The reason for this situation was primarily the fact that the Union introduced the Copenhagen criteria for membership, which meant that the Union analysed each candidate separately. Moreover, the limited cooperation was also caused by the economic differences between countries of the Group, as well as various scenarios

48 Ibidem.

49 K. Żarna, Między Wschodem a Zachodem. Stowacja a Sojusz Pótnocnoatlantycki (1993-2004) [w:] Polityka i Społeczeństwo, 7/2010, s. 219. 
of enlargement towards the east which gave rise to rivalry instead of the desired cooperation.

The Copenhagen criteria were formulated at the EU summit in June 1993. It was emphasised that the countries of Central and Eastern Europe associated with the European Union would become members of the community after fulfilling the following conditions:

- they should remain stable institutions which guarantee the functioning of democracy and the rule of law, respect for human rights and the protection of minority rights,

- they should ensure the functioning of an efficient market economy that would be able to face up to competition within the Union,

- they should have the capacity to fulfill the obligations of membership in the Union,

- they should be able to incorporate laws regulating the EU into national law ${ }^{50}$.

An example of the rivalry within the Group was lobbying the so-called "small enlargement" by the Hungarians. According to Katarzyna Kołodziejczyk-Konarska, Hungary and other small countries are trying to „break free” from Poland, which is the largest country negotiating membership, and thus creating the most problems for the EU. These countries fear that the protracted negotiations with Poland would drive them from EU funds. For this reason, Hungarians, Czechs, Estonians and Slovenes dream of a quick little enlargement and enjoy financial benefits without sharing them with Poland, which, because of its size, will consume a large part of the EU budget ${ }^{51}$.

Putting emphasis on their own national interests over the interests of the Group resulted in limiting the cooperation. An example of that was the withdrawal of the Czech Republic and Slovakia from the protest against the Union plan to establish a ten-year transitional period for the equal use of agricultural funds for all candidate countries. The danger of slowing down the accession split the united front chosen initially by the Visegrad Group effectively. The agricultural sector of

50 K. Gawron - Tabor, op. cit., s. 194-195.

51 K. Kołodziejczyk-Konarska, Proces rozszerzenia Unii Europejskiej na państwa Europy Środkowej $i$ Wschodniej [w:] Unia Europejska, nowy typ wspólnoty międzynarodowej, E. Halizak, S. Parzymies (red.), Warszawa 2002, s. 269. 
the Czech Republic and Slovakia is much less important for the general economy of these countries than is the case of Poland and Hungary, so the introduction of this transitional period would mean smaller losses for Prague and Bratislava than delayed accession ${ }^{52}$.

As mentioned before, it was the national interest which mainly determined the intensity of cooperation within the Visegrad Group. Undoubtedly, the common goal of each member of the Group was final integration with the EU on the best conditions. As a result, a fragmentary cooperation in the format of Visegrad was initiated on the levels of ministers, prime ministers or chief negotiators. A particularly intensive period of Visegrad cooperation in the accession process were the years 2002 - 2003, in which the prime ministers of Poland, the Czech Republic, Slovakia and Hungary met four times ${ }^{53}$.

The result of the meetings in the accession period was working out a common stance on the issue of organising the accession referendums. During the meeting in Krynica, in September 2002, the prime ministers of the four states agreed that they would be held one after another, starting from the state in which the support and the regulations on the validity of the referendum offered the greatest probability of ultimate success ${ }^{54}$.

Finally, the Visegrad Group countries, together with seven other countries, became members of the European Union on 1 May2004, which, along with membership of the North Atlantic Alliance, meant the final accomplishment of the objectives of the Declaration of 15 February 1991 which formed the format of Visegrad. The integration with NATO and the European Union situated Poland, Czech Republic, Slovakia and Hungary in the sphere of influence of the Western security system, which contributed significantly to increasing the level of safety in these countries. A lot of factors contributed to this success and one was them was starting regional cooperation and the joint strive for aspirations and goals. Despite the differences and the limitation periods in the cooperation, the Visegrad Group proved to be an effective formula, demonstrating the ability of young democracies to take joint action to achieve the goals which had been set.

52 K. Gawron-Tabor, op. cit., s. 235.

53 Ibidem.

54 Ibidem, s. 257. 


\section{Visegrad Group's operations in the Western security system - selected projects of V4 within NATO and the European Union}

Accession to the European Union and NATO constituted a test of loyalty, trust, decision-making and consensus on security issues in the region for the Visegrad Group countries. The projects undertaken within the V4 have not always had tangible results.

The greatest challenge for the countries of the Visegrad Group is to ensure military, economic and financial safety for its citizens. Faced with the still unresolved Ukrainian-Russian conflict, this task is extremely difficult. Russia's interference in eastern Ukraine and the sanctions imposed on the Russian Federation by the European Union have divided the V4 countries. The ban on exports of goods to the Russian Federation has become an economic challenge for Hungary, the Czech Republic and Slovakia. The connections which these countries have with the Russian companies investing in their area have been blocked, which led automatically to the suspension of Russian investments ${ }^{55}$. Russia takes advantage of the discrepancy in the Visegrad Group and such discrepancy confirms the lack of unity in the EU. A variety of opinions of Central European countries regarding the Russian Federation reveals that the risks are perceived differently, which, in the long term, impedes cooperation, particularly in the field of regional security.

Achieving membership in the European Union and NATO also poses a question about the meaning of the further functioning within the Visegrad group. The purpose which they achieved and the new reality meant that Poland, Hungary, the Czech Republic and Slovakia had to set new directions.

In a declaration signed on 12 May 2004 in Kromieryż, the Prime Ministers of the Visegrad countries found that the key objectives contained in the Visegrad Declaration of 1991 had been achieved and pledged to develop further cooperation of the Visegrad Group as member states of the European Union and

55 M. Gniazdowski, J. Groszkowski, A. Sadecki, Wyszehradzka kokofonia wobec konfliktu rosyjsko-ukraińskiego, http://www.osw.waw.pl/pl/publikacje/analizy/2014-09-10/ wyszehradzka-kakofonia-wobec-konfliktu-rosyjsko-ukrainskiego [dostęp: 02.01.2016 r.] 
$\mathrm{NATO}^{56}$. Further Visegrad cooperation within the European Union, NATO and other international organisations was identified in Guidelines on future areas of cooperation within the Visegrad Group attached to the Kromieryż Declaration, including:

- Active contribution to the development of the Common Foreign and Security Policy, including the policy of „Wider Europe - New Neighbourhood” and the European Union's strategy towards the Western Balkans,

- Active participation in the development of the Common Security and Defence Policy as a contribution to strengthening the relations between the EU and NATO to deepena meaningful dialogue between the two organisations,

- Consultation and cooperation within the framework of NATO and on its defence capabilities,

- Involvement in the strengthening of transatlantic solidarity and cohesion,

- Cooperation based on the experience of the Visegrad Group in promoting a common understanding of security between the countries aspiring to European and Euro-Atlantic institutions ${ }^{57}$.

Therefore, several areas of mutual commitment were developed Among the most important areas were: economic, business, energy security, military cooperation, the influence on countries outside the EU, especially on countries in Eastern Europe (Russian Federation, Belarus, Ukraine and Moldova), the Balkans and Caucasus, and technological cooperation.

In this part of the article, the authors draw attention to the joint ventures undertaken by the Visegrad countries for security in the framework of NATO and the European Union. These projects include defence cooperation, which was an essential element for the functioning of the Visegrad format since its inception. The accession to the North Atlantic Alliance and the European Union enabled the implementation of cooperation in a wider than ever range. The basic document which formulates defense cooperation is The long-term vision of deepening cooperation in the defense signed on 14 March 2014 in Visegrád. The document

56 Informacja na temat Grupy Wyszehradzkiej, Biuro Spraw Międzynarodowych i Unii Europejskiej, s. 8.

57 Załącznik nr 5. Wytyczne w sprawie przyszłych obszarów wspótpracy wyszehradzkiej, [w:] K. Gawron-Tabor, Wspótpraca państw Grupy Wyszehradzkiej w procesie integracji europejskiej w latach 1989 - 2009, Dom Wydawniczy DUET, Toruń 2013, s. 340-341. 
specifies the following areas of interest of Visegrad cooperation in the field of defence:

- The development of defence capabilities and acquiring the necessary equipment,

- Forming multinational military units and conducting activities with an international profile,

- Education, training and military exercises ${ }^{58}$.

The development of the defence capabilities of the Visegrad Group countries necessary for the effective functioning of NATO and the European Union is carried out in accordance with NATO's smart defence initiative, involving the coordinated development of military capabilities between NATO member states. The initiative provides for the sharing and exchange of capacity among members in order to minimsze financial outlays while raising the level of their quality ${ }^{59}$. DThe declaration of the Visegrad Group signed on 18 April 2012 Responsibility for strong NATO listed specific actions to contribute to the development of an intelligent smart project, including:

- Training air controllers (FAC / JTAC),

- Chemical, biological, radiological and nuclear defence (CBRN),

- Joint logistics,

- Medical institutions, multinational experimentation,

- Building common capacity for maritime air patrols,

- Counter improvised explosive devices training $(\mathrm{C}-\mathrm{IED})^{60}$.

Another platform of the Visegrad cooperation distinguished in The long-term vision of deepening cooperation in the defense efforts are the efforts aimed at forming multinational military units and conducting activities with an international profile. The accomplishment of this idea is the appointment of joint module formations,

58 M. Sterowaniec, T. Kacała, Międzyparlamentarny Wymiar Wspótpracy w ramach Grupy Wyszehradzkiej, s. 188., http://www.kpsw.edu.pl/pobierz/wydawnictwo/miscellanea/ nr5/11_1_serowaniec_kacala.pdf, (dostęp: 3.01.2016 r.).

59 Smart defense, http://www.nato.int/docu/review/topics/en/Smart-Defence.htm, (dostęp: 3.01.2016 r.).

60 Deklaracja Grupy Wyszehradzkiej, Odpowiedzialność za silne NATO, http://www.msz. gov.pl/resource/ee1c8d3f-ff70-4283-87ba-8b1cc2c388cb (dostęp: 3.01.2016 r.). 
which can then be offered to the European Union and NATO as an instrument to achieve security and defence policy ${ }^{61}$.

One of such projects also implemented to emphasise the sustainability of the Visegrad Declaration, and especially to ensure the security of the region, is the Visegrad Battle Group within the European Union. The document setting it up was signed in March 2014 in Visegrád by the defence ministers of Poland, Hungary, The Czech Republic and Slovakia. The legitimacy of the creation of the battle group was reduced to deepening the cooperation in the framework of the Common Security and Defence Policy of the European Union and also to the consistency of security policy towards the Russian Federation in cooperation with the United States ${ }^{62}$. In the authors' opinion, this decision, since the accession of the V4 countries to NATO and the EU, is the most important decision of a strategic character. Poland should determine the courses of action in the project. As a leader, with the biggest military and territorial potential, it must take responsibility for the effectiveness of the initiative.

The Visegrad EU Battle Group took over command on 1 January 2016. Its duty will last until 30 June 2016. The command group was formed in Cracow, in the Land Operations Center ${ }^{63}$. The Group has approximately 3.9 thousand soldiers, half of whom are Poles. The Czech Republic has approx. 800 soldiers, Hungary - approx. 600 and Slovakia - approx. 450. The task of the European Union Battle Group is to work for a period of from 30 to 120 days at a distance of $6000 \mathrm{~km}$ from Brussels. The group is supposed to act in humanitarian, stabilisation, peace enforcement, preventive missions.

The creation of a joint combat group within the European Union strengthened relationships among the "Visegrad Four" on $t$ issues of shaping the security, developing defence policy and confirming the sense of further cooperation in Central Europe.

61 M. Sterowaniec, T. Kacała, op. cit., s. 188.

62 G. Friedman, Visegrad: A New European Military Force, https://www.stratfor.com/ weekly/20110516-visegrad-new-european-military-force, [dostęp: 02.01.2016 r.].

63 M. Kozubal, Sasiedzi tworzq wspólna grupe bojowa, „Rzeczpospolita”, 08.11.2015, http://www.rp.pl/Sluzby-mundurowe/311089941-Sasiedzi-tworza-wspolna-grupe-bojowa. html [dostęp: 02.01.2016 r.]. 
The multinational defensive formation composed of soldiers of the Visegrad Group aimed to function within the framework of the North Atlantic Alliance is also the land component called „Spearhead of NATO”. Spearhead - Very High Readiness Joint Task Force, (VJTF), which was created as part of the NATO Response Force operating in the form of an international army brigade with around 5 thousand soldiers. In principle, a part of Spearhead should be ready for use within 48 hours, the rest of the formation during the week. The creation of the Very High Readiness Joint Task Force is part of NATO's Readiness Action Plan, agreed at the summit of NATO in Newport, Wales.

According to the portal wPolityce.pl, Poland will become the framework nation of the Spreadhead land component in 2020. The Deputy Minister of the Ministry of National Defence, Tomasz Szatkowski, noted that this will be the component that will consist roughly of five battalions. We intend, of course, as a framework state to invite our partners to cooperate with the rotation, including the Visegrad Group. The person responsible for international cooperation in the Ministry of Defence also added that there is a preliminary agreement that a portion of this component was the contribution under the flag of Visegrad ${ }^{64}$.

The third area highlighted in The long-term vision of deepening cooperation in the defense is cooperation in the fields of education, training and military exercises, which is implemented under the Visegrad Group Military Educational Programme (VIGMILEP). The programme was established to coordinate efforts for the collection, sharing and use of educational research opportunities in the Visegrad countries, which will contribute to raising the level of education and training of military officers and other experts in the field of security and defence in accordance with the standards of NATO and the European Union ${ }^{65}$.

Another area of cooperation, to which the Visegrad Group devotes more and more attention, is to ensure energy security. The raw material most important

64 Ambitne plany MON: Polska państwem ramowym ladowego komponentu szpicy NATO. Państwa Grupy Wyszehradzkiej zgodzity się na wspótprace, http:// wpolityce.pl/polityka/276584-ambitne-plany-mon-polska-panstwem-ramowymladowego-komponentu-szpicy-nato-panstwa-grupy-wyszehradzkiej-zgodzily-sie-nawspolprace?strona $=1$ [dostęp 3.01.2016 r.].

65 Joint Communiqué of the Visegrad Group Ministers of Defence, http://www. visegradgroup.eu/calendar/2015/joint-communique-of-the [dostęp 3.01.2016 r.]. 
in this field is natural gas. The events which occurred during the energy crises in 2006, and particularly in 2009, when Russia stopped gas supplies to Ukraine, convinced Poland, Hungary, the Czech Republic and Slovakia of the necessity for diversification of "blue fuel". Furthermore, what these countries have in common is that they have gas supplies only from the Russian source and there is a lack of a common energy market, the system of main pipeline running east-west and geographical environment ${ }^{66}$. In the framework of energy cooperation and ensuring the security of natural gas supply, the states established a number of projects, which include:

- expanding the transmission infrastructure of natural gas, electricity and petroleum products - Energy Corridor North-South ${ }^{67}$, (Map 2)

- joint efforts to obtain funds from the European Union, financing or co-financing of projects which concern energy security ${ }^{68}$,

- cooperation in the field of nuclear energy, particularly important for Poland, considering the fact that the other V4 countries already have nuclear power plants,

- influencing the decisions of the EU energy policy of the Russian Federation through coherent policy,

66 T. Kubin, Grupa Wyszehradzka - perspektywy dalszej wspótpracy, „Atheneum. Polskie Studia Politologiczne", 42/2014, Wydawnictwo Adam Marszałek, Toruń, s. 31.

67 Corridor North - South consists of infrastructure projects in the field of gas, electricity and oil, which will link the markets of Central Europe with each other as well as from the western part of the continent. In the gas sector, the Corridor aims to create a coherent transmission network, consisting of pipelines and interconnectors, extending from the Baltic Sea to the Adriatic coast. The corridor is also to extend the existing pipelines so that oil supplied to Europe via the Baltic Sea or the Adriatic Sea could then be freely transported across Central Europe. As for the electricity sector, the most important thing is the construction of high voltage power lines that will connect the Baltic countries - which are still lonely islands - with the rest of Europe. Infrastructure, which in effect created, will be essential to ensure energy security in Central Europe. The entire European Union, which thanks to the implementation of the corridor will increase its competitiveness, will benefit from strengthened national industry and facilitating the coordination of strategic objectives.

68 In the region of Central Europe, The European Investment Bank co-finances, among others, the Hungarian-Croatian interconnector, modernisation of the electricity network in the Czech Republic and Hungary as well as construction of installations in the area of renewable energy in the Czech Republic and Poland (wind farms). 
- harmonisation of the legal framework related to foreign investments in the V4.energy area ${ }^{69}$.

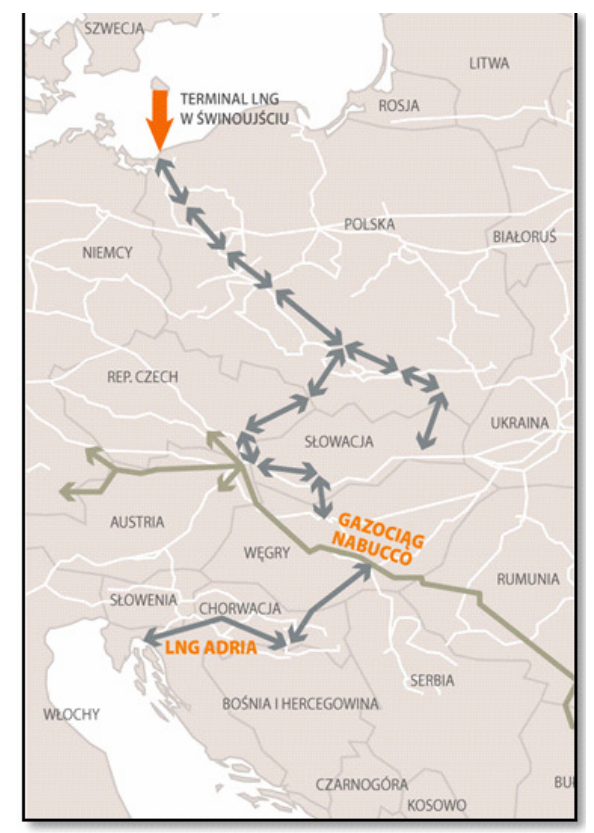

Source: http://www.gaz-system.pl/nasze-inwestycje/integracja-z-europejski-systemem/korytarzpolnoc-poludnie/ [dostęp: 03.01.2016 r.]

\section{Map 2. The route of the North - South Corridor}

It is worth noting that the concept of the North-South Corridor, mentioned above, is designed to form, respectively, the Polish and Croatian LNG terminals and the Nabucco pipeline ${ }^{70}$. The immediate success of this investment was receiving the first delivery of gas from Qatar at the end of 2015. The LNG terminal in Świnoujście is an important element of Polish energy security as well as the V4 countries. With the new pipelines, interconnectors virtual reverse on the Yamal pipeline, as well as the underground warehouses and its own production, the terminal will strengthen Poland's gas independence and prevent crises in the supply of Russian

69 T. Kubin, Grupa Wyszehradzka - perspektywy dalszej wspótpracy, „Atheneum. Polskie Studia Politologiczne", 42/2014, Wydawnictwo Adam Marszałek, Toruń, s. 32-33.

70 K.M. Pronińska, Bezpieczeństwo energetyczne w stosunkach UE-Rosja. Geopolityka i ekonomia surowców energetycznych, Dom Wydawniczy ELIPSA, Warszawa 2012, s. 346. 
natural gas. The investment will enable the receipt of gas by sea from virtually any direction in the world; thus it will make other countries of the Visegrad Group independent of the Russian Federation.

Despite many areas in which the V4 countries develop cooperation in energy security issues, there are also many differences regarding the common energy policy. A different policy towards the Russian Federation should be particularly emphasised. Poland and the Czech Republic are able to cope without Russian imports of raw materials, while Hungary and Slovakia are almost 100\% dependent on them. This makes the energy policy of these countries relatively different from the Czech or Polish; moreover, it could be argued that it is friendly towards Russia. Another convergent issue in the Visegrad Group is Hungarian policy towards Russia and the South Stream gas pipeline. The Russians presenting an attractive energy offer to Hungarians led to the withdrawal of Hungarian companies from the implementation of the Nabucco project and the weakening of Visegrad cooperation. The South Stream project was suspended thanks to the European Commission and because of the Russian-Ukrainian war. The whole episode may halt investments in the North-South Energy Corridor. This will happen because of Hungary, which is going to block the connector to the planned LNG gas terminal on the Croatian island of Krk and gas from the Caspian Sea from the Trans Adriatic Pipeline. The above situation may create a threat to Hungarian total reliance on Russian gas, and hence the expansion of the LNG terminal in Swinoujście by Poland, which will become the only alternative for the Visegrad Group ${ }^{71}$. Finally, it must also be noted that cooperation in the field of energy security of the Visegrad Group countries has a significant impact on energy companies, which are able to change political and economic decisions reached at the state level with their internal policy.

Regional cooperation within the Visegrad Group implies many events which have a positive or a negative effect on the image of Central Europe in the European Union. After more than a decade of EU common experience, we can say that the Central European region should be identified with the policy pursued by Poland, Hungary, the Czech Republic and Slovakia. In particular, the issues relating to

71 W. Jakóbik, Wegry uderzaja w plany Grupy Wyszehradzkiej na korzyść Rosji, http:// biznesalert.pl/jakobik-wegry-uderzaja-w-plany-grupy-wyszehradzkiej-na-korzysc-rosji/ [dostęp: 03.01.2016 r.]. 
security in the face of the unpredictable Russian neighbour should tighten mutual relations between the four countries. The unified voice of 65 million citizens of other European Union countries should provide greater strength and are the token of the Central European rank. The ability to work out a common position, despite many differences and sometimes conflicting interests on matters of strategic importance for the security of the EU, may strengthen the position of the region. However, there are differences that arise in the policies of the states. Perhaps this is because the Visegrad Group does not have institutionalised cooperation, perhaps because the story and the yoke of Soviet domination does not enable a return to dependence even on the closest ally. One can trace more aspects that will undermine the unity of the V4. In conclusion, the authors believe, only cooperation, following the example of the Scandinavian and the Benelux countries, will make it possible to develop strong positions in the European Union and NATO, which will enable the Visegrad Group countries to remain safe and prevent their violation.

\section{Summary and conclusions}

The provisions of the Yalta Conference of February 1945 placed Central Europe in the Soviet sphere of influence, effectively separating Poland, the Czech Republic, Slovakia and Hungary from Western European and transatlantic integration processes. As the result of the implementation of communist ideas in these countries, they had been included into the military and economic structures dominated by the Soviet Union - the Council for Mutual Economic Assistance and the Warsaw Pact. Their co-existence in the Soviet zone became a source of regional cooperation, which was then the basis for the proclamation, on 15 February 1991, of the Visegrad Triangle.

The main aim of the Visegrad cooperation was inclusion in Western economic systems and security through integration with the European Union and the North Atlantic Alliance. Due to the low level of institutionalisation, cooperation was exposed to limitations resulting from the political situation in the Member States. The result of the divergent positions of political forces in the Czech Republic and 
Slovakia, relative to regional cooperation, was a period of low cooperation and the individual character of participation in the accession process.

The enlargement of NATO and the European Union to include Poland, the Czech Republic, Slovakia and Hungary was the achievement of the objectives contained in the Declaration of 15 February 1991 appointing the Visegrad Group. The emergence of new challenges and threats in the early twenty-first century and the measurable benefits from regional cooperation resulted in the extension and redefinition of the purpose of the existence of the Visegrad Group, functioning now within the European Union and NATO.

The article presents the joint commitment of the Visegrad countries in raising the level of security of the Union and the Alliance as a whole, which included: efforts to strengthen the Common Security and Defence Policy of the European Union, energy policy coordination and the development of defence cooperation, expressed in the Long-term vision of deepening cooperation in defenve.

In the face of negative processes a disintegration affecting the shape of the international security environment, coordination of the Visegrad Group at the political level and strengthening defecse cooperation will be crucial to effectively counteract new threats. Establishing a Visegrad Battle Group is the desired direction of cooperation, the experience of which could be used in forming the "Spreadhead" land component of NATO. However, the negative aspect of cooperation is now since the beginning of its existence, the dominance of individual national interests over the interests of the entire Group. This is now reflected in the different stance of members of the Group towards the policy of the Russian Federation.

\section{Bibliography}

1. A. Czarnocki, Europa jako region wspótistnienia Wschód-Zachód w latach 19721989, Wydawnictwo Uniwersytet Marii Curie-Skłodowskiej, Lublin 1991.

2. A. Czubiński, Europa XX weku, Wydawnictwo Poznańskie, Poznań 2008.

3. B. Osadnik, Nowy regionalizm w Europie Środkowo-Wschodniej. Grupa Wyszehradzka [w:] „Bezpieczeństwo państw Grupy Wyszehradzkiej. Nadzieje i realia”, J. Przewłocki, B. Osadnik (red.), Wydawnictwo Uniwersytetu Śląskiego, Katowice 1995. 
4. Czechy a Polska na progu czasów nowożytnych, J. Panek, Wydawnictwo Adam Marszałek, Toruń 2014.

5. E. Czarkowska, Interwencja Związku Radzieckiego na Węrzech w 1956 r., Wydawnictwo Adam Marszałek, Toruń 2007.

6. F. Gołembski, Grupa Wyszehradzka - próba realizacji koncepcji wielostronnej wspótpracy w Europie Środkowej, „Sprawy międzynarodowe”, Zeszyt 3 (XLVII) 1994, PISM, Warszawa.

7. Grupa Wyszehradzka - 20 lat wspótpracy, A. Czyż, „Atheneum” Polskie Studia Polityczne, 42/2014, Wydawnictwo Adam Marszałek.

8. J. Kukułka, Historia wspótczesna stosunków międzynarodowych 1945-1994, Wydawnictwo Naukowe „Scholar”, Warszawa 1994.

9. J. Panek, Czechy a Polska na progu czasów nowożytnych, Wydawnictwo Adam Marszałek, Toruń 2014.

10. J. Wiejacz, Grupa Pentagonale i miejsce Polski, „Polska w Europie”, czerwiec 1991 r.

11. K. Gawron - Tabor, Wspótpraca państw Grupy Wyszehradzkiej w procesie integracji europejskiej w latach 1989 - 2009, Dom Wydawniczy DUET, Torun 2013.

12. K. Gawron- Tabor, Wspótpraca państw Grupy Wyszehradzkiej w procesie integracji europejskiej w latach 1989- 2009, Dom Wydawniczy DUET, Toruń 2013.

13. K. Kołodziejczyk - Konarska, Proces rozszerzenia Unii Europejskiej na państwa Europy Środkowej $i$ Wschodniej [w:] Unia Europejska, nowy typ wspólnoty międzynarodowej, E. Halizak, S. Parzymies (red.), Warszawa 2002.

14. K. M. Pronińska, Bezpieczeństwo energetyczne w stosunkach UE-Rosja. Geopolityka i ekonomia surowców energetycznych, Dom Wydawniczy ELIPSA, Warszawa 2012.

15. K. Pełczyńska- Nałęcz, Stosunki polityczne między Polska a Rosja po 1990 r. [w:], Białe plamy - Czarne plamy. Sprawy trudne w polsko-rosyjskich stosunkach 1918-2008, A.D. Rotfeld, A.W. Torkunow (red.), Polski Instytut Spraw Międzynarodowych, Warszawa 2010.

16. K. Żarna, Między Wschodem a Zachodem. Stowacja a Sojusz Północnoatlantycki (1993-2004) [w:] Polityka i Społeczeństwo, 7/2010.

17. L. Ciamaga, Od wspótpracy do integracji: zarys organizacji i działalności w latach 1949-1964, „Książka i Wiedza”, Warszawa 1965

18. M. Herman, Grupa Wyszehradzka. Narodziny, rozwój, perspektywy, Polski Przegląd Dyplomatyczny, nr 2/2001.

19. P. Bukalska, Punkt widzenia. Nowa Grupa Wyszehradzka w nowej Unii Europejskiej - szanse i możliwości rozwoju, Wyd. Ośrodek Studiów Wschodnich, Warszawa 2003.

20. P. Deszczyński, M. Szczepaniak, Grupa Wyszehradzka. Wspótpraca polityczna i gospodarcza, Wyd. Adam Marszałek, Toruń 1995.

21. P. Wandycz, WiekXX, [w:] „Historia Europy Środkowo-Wschodniej, t. 1, J. Kłoczkowski (red.), Instytut Europy Środkowo-Wschodniej, Lublin 2000. 
22. R. Bierzanek, Wspótczesne stosunki międzynarodowe, Państwowy Instytut Wydawniczy, Warszawa 1980.

23. R. Zięba, „Nowy regionalizm” w Europie a Polska, „Sprawy Międzynarodowe”, Zeszyt 1-2/455/1992, PISM, Warszawa.

24. T. Kubin, Grupa Wyszehradzka - perspektywy dalszej wspótpracy, „Atheneum. Polskie Studia Politologiczne", 42/2014, Wydawnictwo Adam Marszałek, Torun.

25. W. Pawłowski, Trójkąt, sześciokąt i reszta Europy, „Polityka”, 23.02.1991 r.

26. Z. Jirasek, A. Małkiewicz, Polska i Czechosłowacja w dobie stalinizmu (1948-1956). Studium porównawcze, Instytut Studiów Politycznych PAN, Warszawa 2005.

\section{Websites}

1. www.visegradgroup.eu

2. www.visegradfund.org

3. www.bbn.gov.pl

4. www.osw.waw.pl

5. www.kpsw.edu.pl

6. www.nato.int

7. www.msz.gov.pl

8. www.stratfor.com

9. www.rp.pl

10. www.wpolityce.pl

11. www.visegradgroup.eu

12. www.gaz-system.pl

13. www.biznesalert.pl 